International Journal of Design and Manufacturing

Technology (IJDMT),

ISSN 0976 - 6995(Print), ISSN 0976 - 7002(Online)

Volume 2, Issue1, January-December (2011), pp. 07-20

(C) IAEME, http://www.iaeme.com/ijdmt.html

\title{
FINITE ELEMENT APPROACH FOR THE PREDICTION OF RESIDUAL STRESSES IN ALUMINUM WORK PIECES PRODUCED BY ROLLER BURNISHING
}

\author{
J.N. Malleswara Rao ${ }^{*}$, Dr. A. Chenna Kesava Reddy ${ }^{2}$, \\ Dr. P. V. Rama $\operatorname{Rao}^{3} \&$ B. Mayuri ${ }^{4}$
}

${ }^{1}$ Assistant Professor, Department of Mechanical Engineering, V. R. Siddhartha Engineering College, Vijayawada-520 007, Andhra Pradesh, India, Ph: 0- 9440301935

* Corresponding Author E-mail: jnmr15827@yahoo.co.in

${ }^{2}$ Professor, Department of Mechanical Engineering, J. N. T. U. College of Engineering, Kukatpally, Hyderabad- 500 072, A. P., India.

${ }^{3}$ Professor, Dept. of Mechanical Engineering, Mahatma Gandhi Institute of Technology, Hyderabad, A. P., India.

${ }^{4}$ Lecturer, Dept. of Mechanical Engineering, V. R. Siddhartha Engineering College, Vijayawada, A. P.

\begin{abstract}
Burnishing is a cold rolling process without removal of metal. A set of precision rollers are used to roll on the component surface with adequate pressure. As a result all the pre- machined peaks gets compressed into valleys thus giving a mirror like surface finish. Surface finish is considered as important factor for the sliding surfaces, in order to have long life. In Burnishing, compressive residual stresses are induced during the process. In the present work, experimental work is carried out to reduce the surface roughness of a specially fabricated aluminum work piece, by roller burnishing process on lathe. High carbon, high chromium roller is used as tool in the roller burnishing process. Various experiments are conducted to investigate the variation of surface roughness $\left(R_{a}\right)$ with respect to the variation of burnishing force. Finite element model is developed to compare the experimental results. The results are found to coincide with the values got from the experimental readings, and the variations are less than $10 \%$.
\end{abstract}

Keywords: Roller burnishing, Compressive Residual Stresses, Surface Roughness value $\mathrm{R}_{\mathrm{a}}$, Burnishing force, plastic deformation, Finite Element Analysis.

\section{INTRODUCTION}

Burnishing is one of the important finishing operations carried out generally to enhance the fatigue resistance characteristics of components. Burnishing tools are used to impart a gloss or fine surface finish, often in processes that involve the cold working of metal surfaces. Burnishing tools are also used for the sizing and finishing of surfaces. A burnishing tool develops a finished surface on turned or bored metal surface by performing a continuous planetary rotation of hardened rolls. The rotation of the rolls increases the yield point of the soft portion of the metal surface at the point of contact. The material in the peaks gets plastic deformation and it is filled up in the valleys, as shown in the Fig. 1. 
International Journal of Design and Manufacturing Technology (IJDMT), ISSN 0976 - 6995(Print), ISSN 0976 - 7002(Online) Volume 2, Issue 1, January-December (2011), @ IAEME

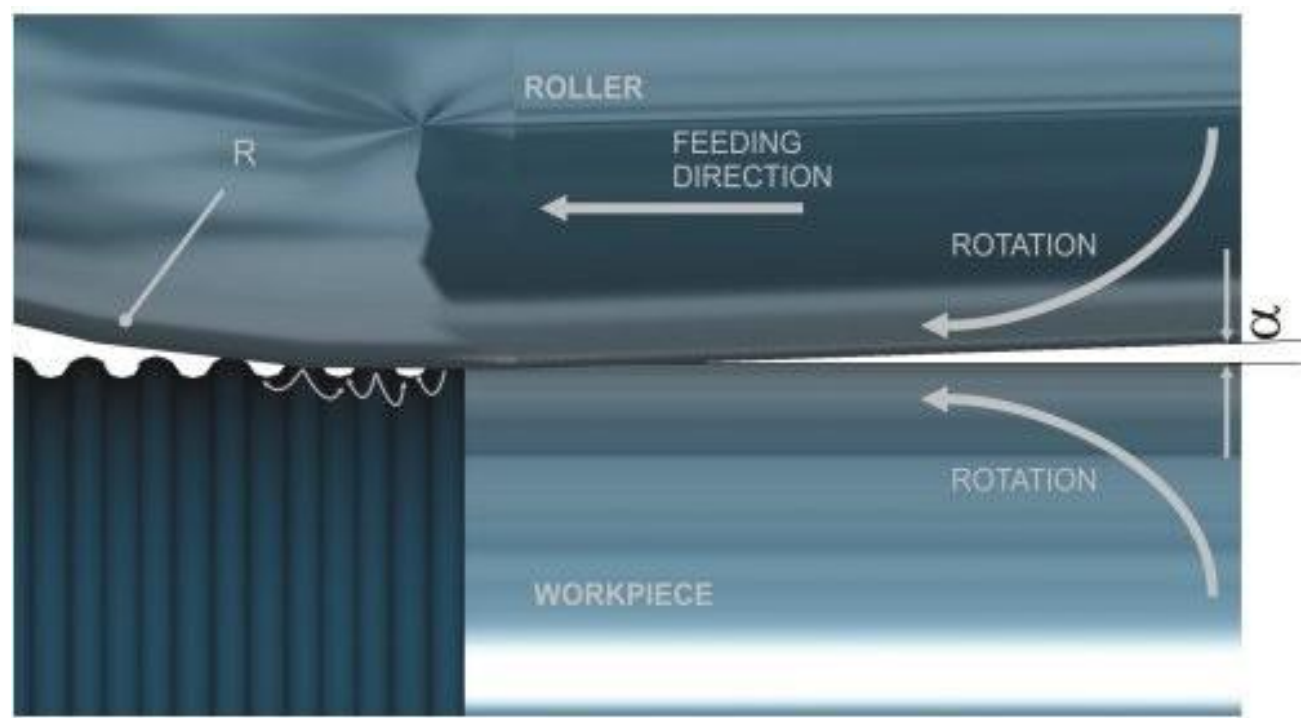

Fig. 1 Schematic of Roller burnishing process.

This point of contact results in the deformation of the metal surface to generate a finished metal surface. There are many types of burnishing tools. Burnishing is not a metal cutting process. In burnishing process, chips are not produced. It is essentially a cold forming process, in which the metal near a machined surface is displaced from protrusions to fill the depressions.

Due to the work hardening of the surface during burnishing, there will be a hardened layer on the surface and it is expected to increase the fatigue resistance of the component. Apart from improvement in surface finish and fatigue strength, burnishing process imparts improved wear and corrosion resistance. There are two types of burnishing processes. i. Ball burnishing and ii. Roller burnishing. The ball materials are hardened alloy steel, carbide, diamond, etc. The roller material is hardened alloy steel. In this paper, experiments with Roller burnishing tool are presented.

Burnishing is most often performed on internal and external diameters. The schematic of Roller burnishing process with indication of residual stress conditions developed by the process is shown in Fig. 2. 
International Journal of Design and Manufacturing Technology (IJDMT), ISSN 0976 - 6995(Print), ISSN 0976 - 7002(Online) Volume 2, Issue 1, January-December (2011), C IAEME

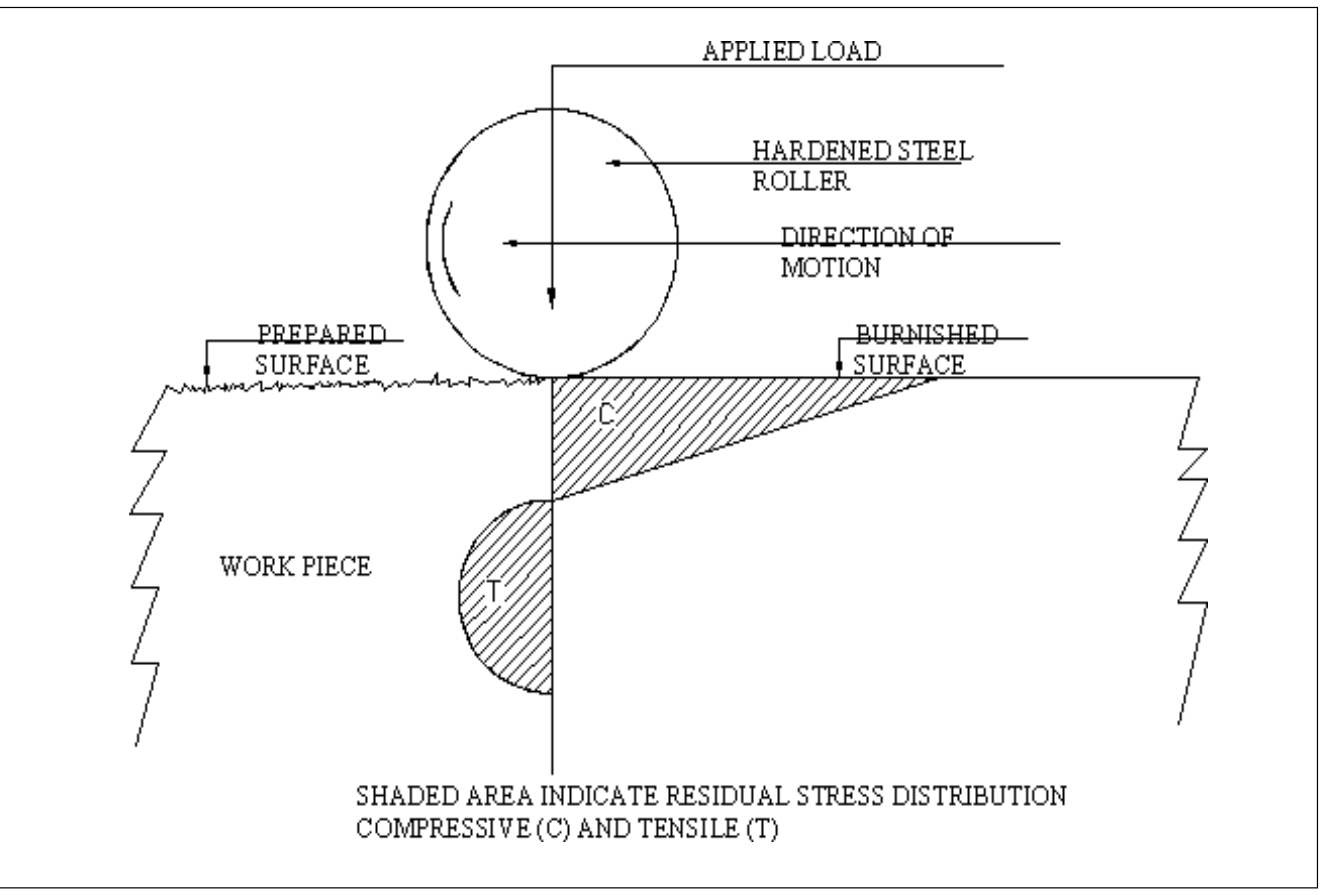

Fig. 2 Residual stress conditions developed by the burnishing process

\section{LITERATURE REVIEW}

Yu. G. Shneider [1] studied the characteristics of burnished components. Wear has important technological and economical significance because it changes the shape of the work piece, and the tool and the interference. R. L. Murthy [2] et al discussed the types and working methods of burnishing process. Burnishing is considered as a cold working process which can be used to improve surface characteristics. Surface roughness and hardness plays an important role in many areas and is factor of great importance for the functioning of machined parts. A. M. Hassan [3] et al explained the effects of ball and roller burnishing on the surface roughness and hardness of some non- ferrous metals. It was suggested by many investigators that an improvement in wear resistance can be achieved by burnishing process.

S. Thamizhmnaii [4] et al presented the surface roughness and hardness investigations on titanium alloy using a roller burnishing tool. N. H. Loh [5] et al presented the investigations on the surface roughness produced by Ball burnishing. B. Kotiveerachari [6] et at studied the effect of burning force on the surface roughness. T. Siva Prasad [7] et al discussed various parameters that will lead to the improvement of surface finish on aluminum components. Finite Element Analysis is discussed by many authors [8-11]. In the present experimental work, the effect of different burnishing forces on surface roughness and residual stress distribution during the burnishing process are studied using Finite Element Analysis (FEA).

\section{A. Parameters affected by Burnishing}

Because of plastic deformation in burnishing operation under cold working conditions, the work piece surface is work hardened. The surface hardness increases considerably. Also, the metal flows on the surface of the work piece during burnishing operation. Due to this flow of metal, any burrs, scratches, micro cracks, etc. on this surface of the work are filled up. Comparison of surface roughness in pre-machined and roller burnished surfaces are shown in Fig. 3. As a result, the number of stress raisers on the surface decreases, thereby increasing the fatigue strength of the work piece. Because of improvement in the surface hardness and surface finish, the surface would become resistant to corrosion and wear. 
International Journal of Design and Manufacturing Technology (IJDMT), ISSN 0976 - 6995(Print), ISSN 0976 - 7002(Online) Volume 2, Issue 1, January-December (2011), @ IAEME

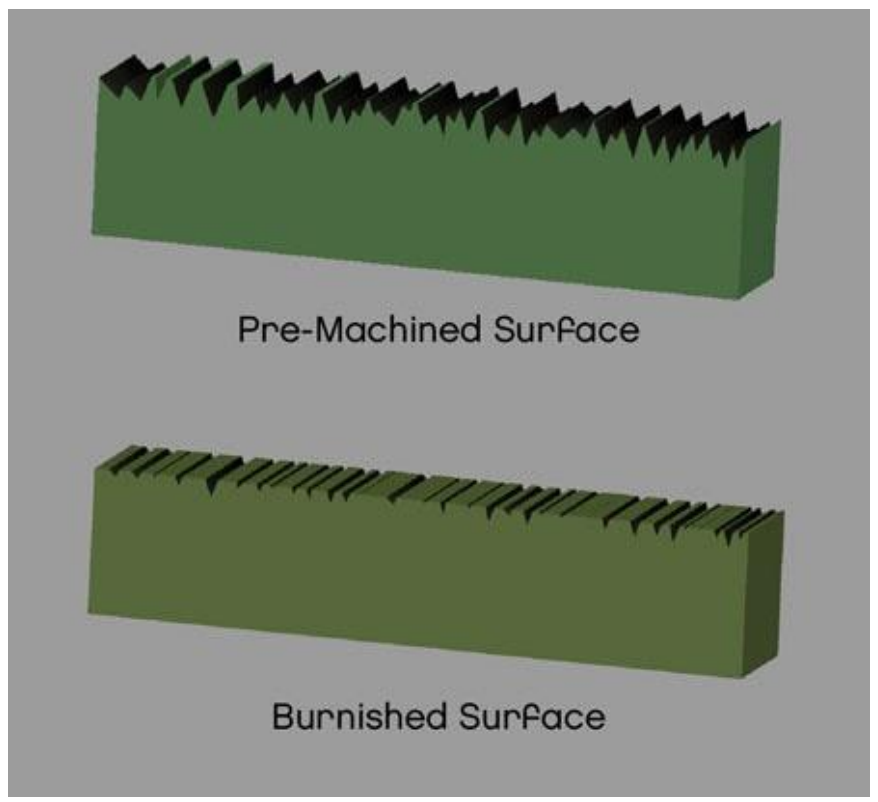

Fig. 3. Comparison of Surface Roughness in the pre- machined surface and Burnishied surface

\section{B. Industrial Applications of Roller Burnishing}

Typical applications for the Roller Burnishing process include Interiors of hydraulic oil brake cylinders, Internal surfaces and taper seat surfaces of valve bodies, Internal surfaces of bushing for connecting rods, Holes for inserting bearings, Internal surfaces of gun barrels, Internal surfaces of brass liners for cast iron valves, External surfaces of shafts for torque converters, Valve seats of fuel pumps, External surface tapers for joints, Bearing Housings, Bearing Bushes, Connecting Rod, GMI Bronze Bushes, Valve guide, Brake cylinder, Master cylinder, Fan rotor shaft, Shock absorber piston rod, Piston, clutch parts, Rotor shaft, cooler shaft, Spherical seat surfaces of oil joints, etc.

\section{Advantages of Roller Burnishing}

1. Mirror finish in one pass. Accurate sixing, close tolerances, eliminates Lapping \& Honing.

2. Improved metallurgical properties, Work hardened surface, increase in fatigue strength.

3. No additional machine investment, attachable to any standard machine tool already present in the shop.

4. Long tool life, No operator skill required low torque and power requirements, maximum parts interchangeability.

\section{ROLLER BURNISHING TOOL}

A Roller burnishing tool is designed and fabricated as shown in Fig. 4. It consists of the following parts. i. Roller ii. Special bolt iii. Nut iv. Bush v.Washers vi. Shank. The shank is fixed in the dynamometer and it is tightened with two bolts. The chemical composition of Roller material is given below:

Fe 97.003, Si 0.18, Mn 0.26, Ni 0.12, Cr 1.44, C 0.99, S 0.007

The Roller has the following properties.

Surface roughness value $R_{a}=0.02 \mu \mathrm{m}$, Hardness $=61$ HRC. 
International Journal of Design and Manufacturing Technology (IJDMT), ISSN 0976 - 6995(Print), ISSN 0976 - 7002(Online) Volume 2, Issue 1, January-December (2011), @ IAEME

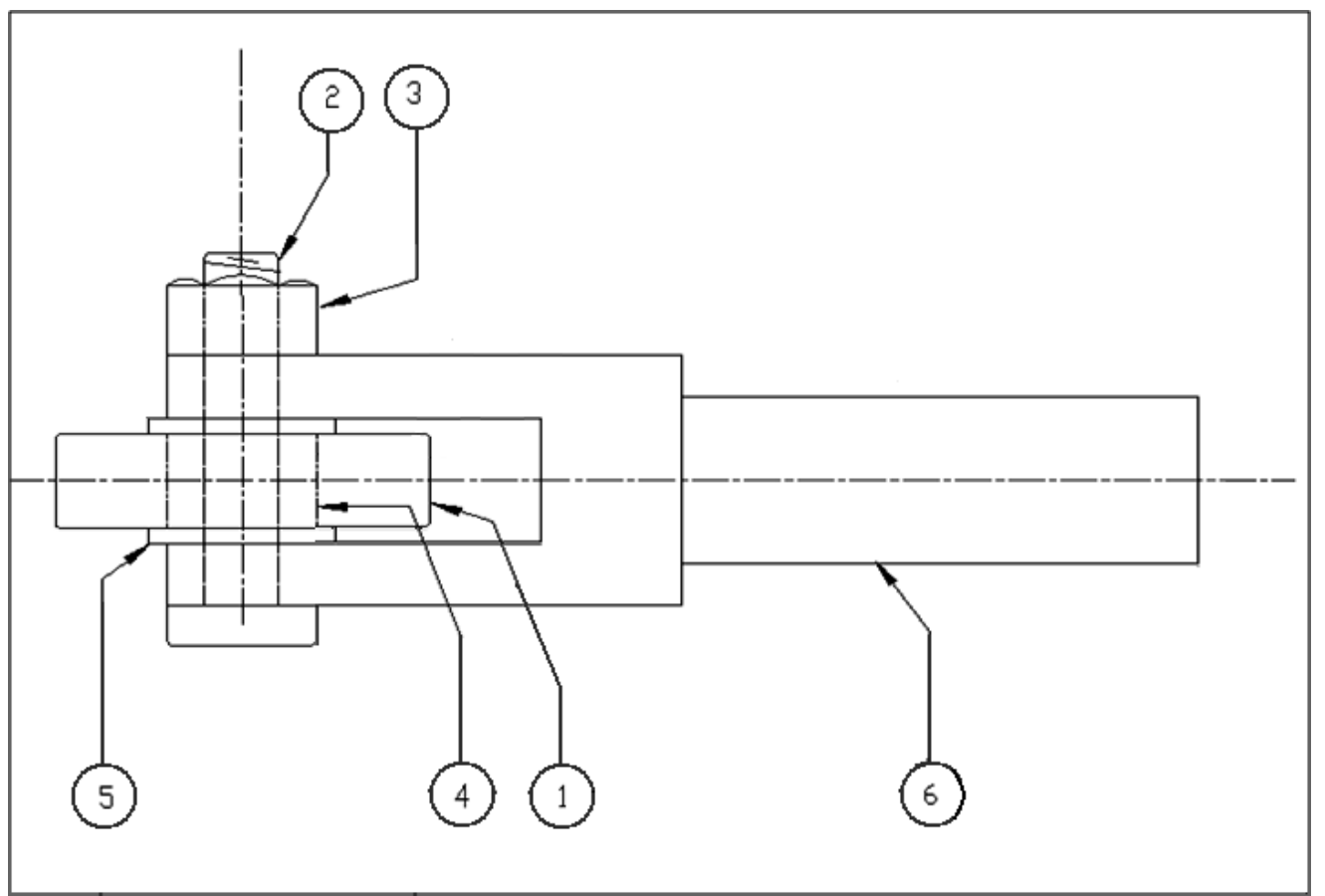

Fig. 4. Roller Burnishing Tool assembly

\section{EXPERIMENTAL SET UP}

\subsection{Equipment}

The Roller burnishing tool is fixed on the Lathe. The experimental set up is shown in Fig. 5. It consists of the following parts. 1. Three jaw chuck 2. Live center 3. Aluminum Work piece 4. Dead center 5. Roller Burnishing tool 6.Dynamometer fixed to the cross slide of Lathe 7. Hand wheel for cross slide 8. Input power to the Dynamometer ix. Strain reader.

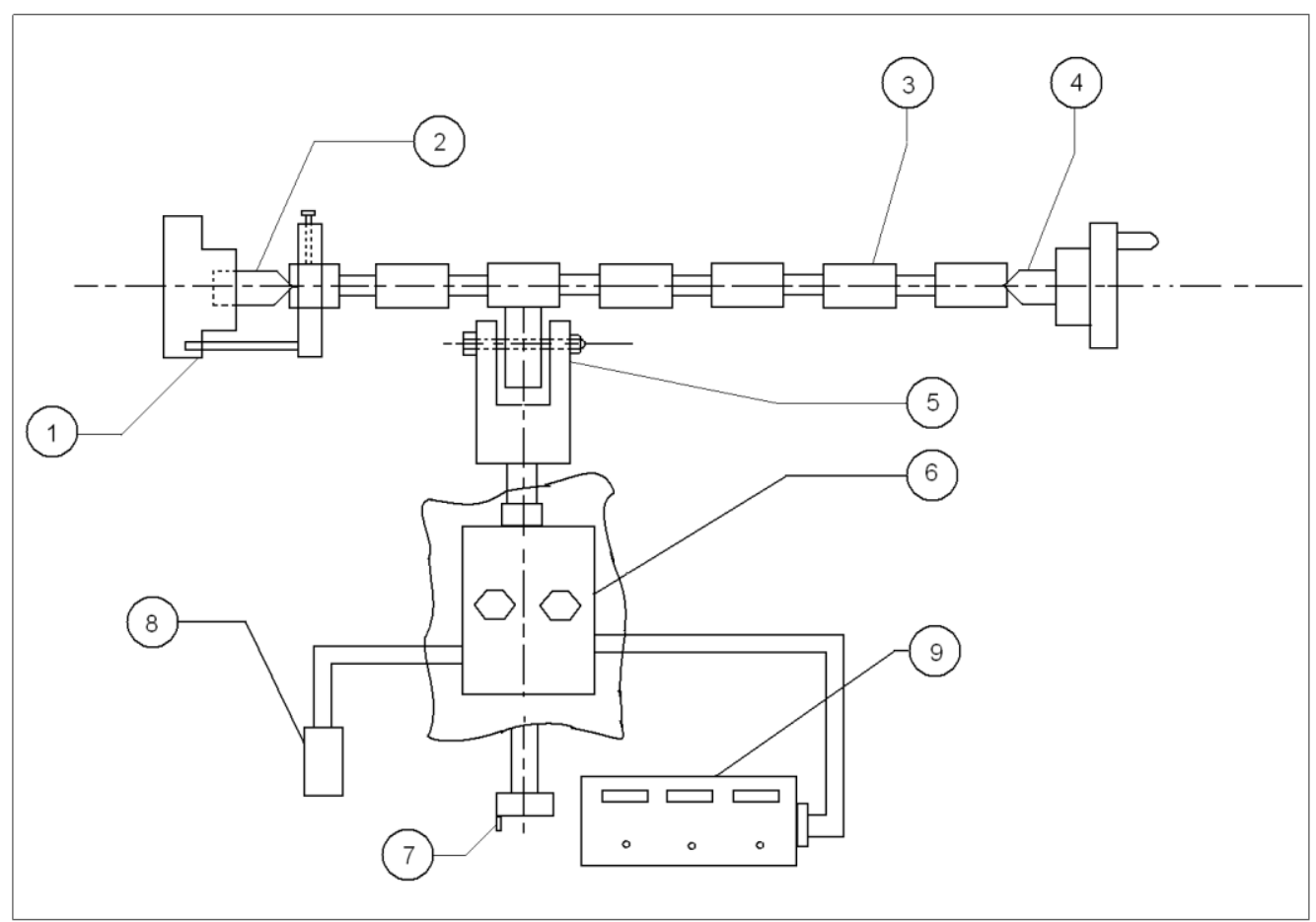

Fig. 5 Experimental set up with Roller burnishing tool 
International Journal of Design and Manufacturing Technology (IJDMT), ISSN 0976 - 6995(Print), ISSN 0976 - 7002(Online) Volume 2, Issue 1, January-December (2011), @ IAEME

\subsection{Work Piece}

Burnishing experiments are conducted on turned aluminum work piece, which is very ductile, corrosive resistant, good conductor and available in the form of round bars. The chemical composition of aluminum specimen (wt \%) is given below:

\section{$\mathrm{Al}$ 93.73, Cu 5.34, Fe 0.3, Si 0.05, Mn 0.55, Zn 0.03}

To conduct experiments with roller burnishing tool, a round bar made of aluminum material is chosen as work piece material. The aluminum work piece is specially fabricated, as shown in Fig. 6. All the dimensions are shown in millimeters in this figure. Photograph of aluminum work piece is shown in Fig. 7.

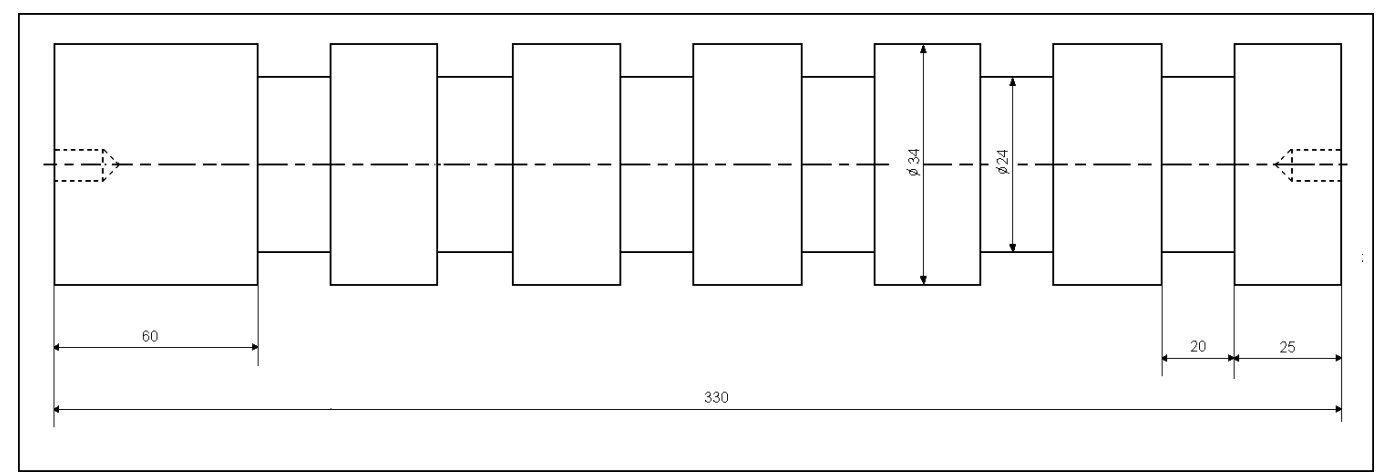

Fig. 6 Aluminum work piece for Roller Burnishing

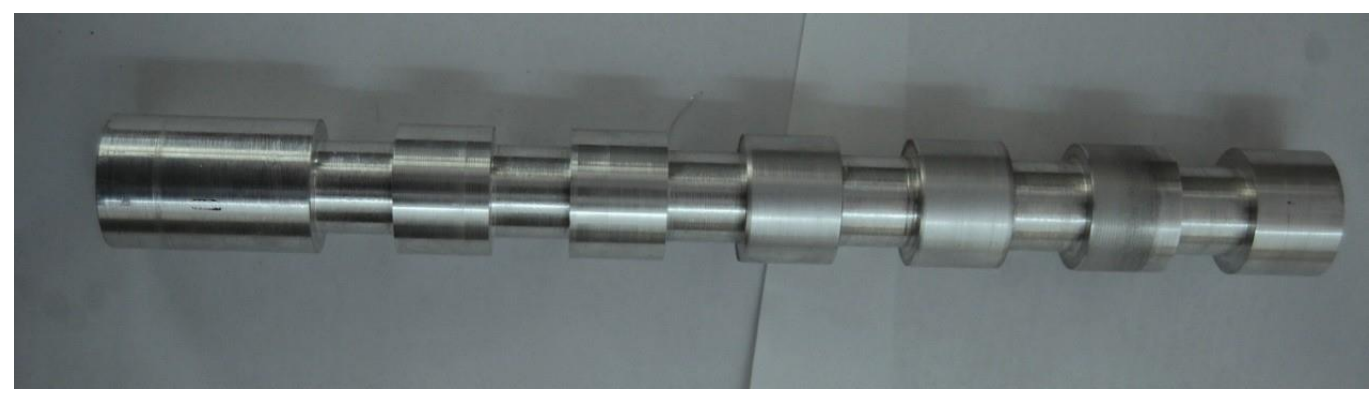

Fig. 7 Photograph of Aluminum work piece

First, the work piece is held in 3- jaw chuck of lathe and facing operation is completed on both sides and centre drilling is completed on both the faces. Then, the work piece is held in between centers of lathe and it is driven through the lathe dog. A high speed steel (H. S. S.) single point cutting tool is fixed in the tool post of the lathe and work piece is turned to have 6 steps and grooves in between them. In actual experiments, by applying different parameters on each step, this long work piece can be utilized as 6 different work pieces.

In the present work, roller having outside diamante of $34 \mathrm{~mm}$ is used for roller burnishing. The tool post and compound rest are removed from the lathe. Dynamometer together with its fixture is held on the cross slide of PSG A 141 Coimbatore make, India and it is tightened with two fixing bolts. The roller burnishing tool assembly is kept in the tool holder of dynamometer and it is held rigidly by two bolts. Burnishing Force i.e., radial component of cutting force (in y- direction) is measured by dynamometer.

Fig. 8 shows the photograph of the experimental set up when roller burnishing tool with $40 \mathrm{~mm}$ diameter roller burnishes an aluminum work piece in PSG A 141 lathe. Fig. 9 shows the photograph of close up view of the experimental set up of roller burnishing with aluminum work piece. 
International Journal of Design and Manufacturing Technology (IJDMT), ISSN 0976 - 6995(Print), ISSN 0976 - 7002(Online) Volume 2, Issue 1, January-December (2011), @ IAEME

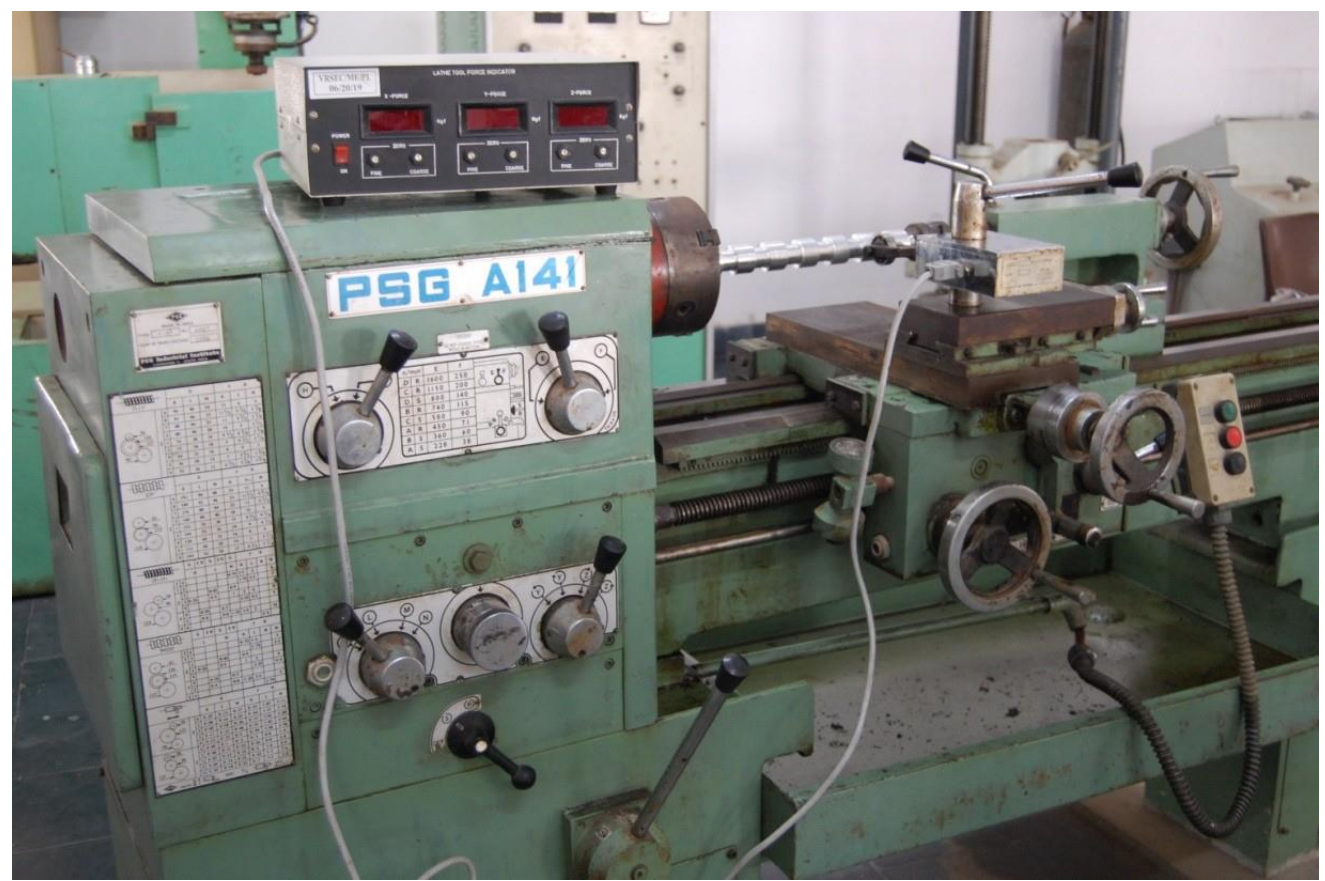

Fig. 8 Photograph showing experimental set up on lathe

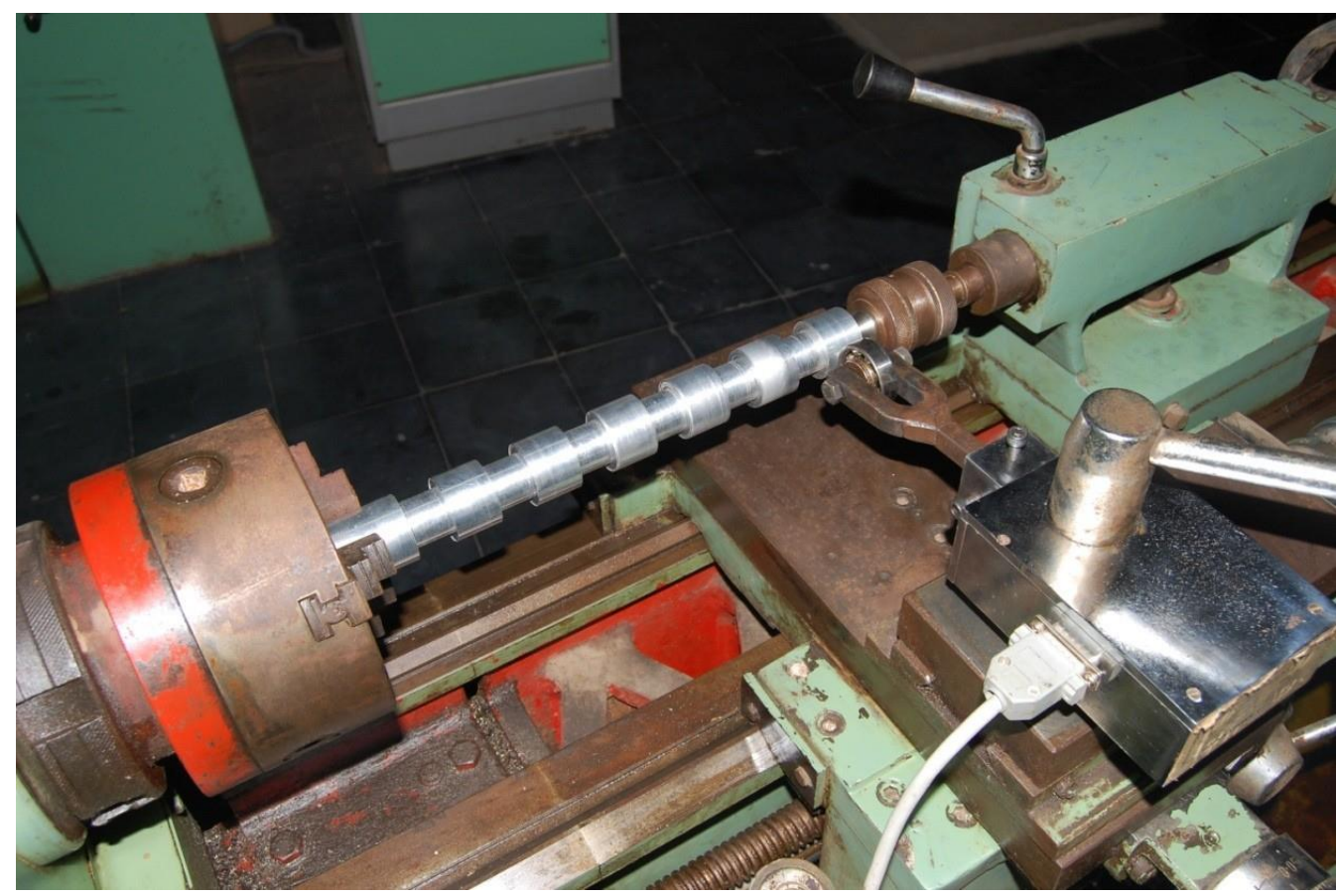

Fig. 9 Photograph showing close up view of aluminum work piece and roller burnishing tool on lathe

\subsection{MEASUREMENT OF SURFACE ROUGHNESS VALUES}

A repetitive or random deviation from the nominal surface which forms the pattern of the surface is known as surface texture. It includes roughness, waviness, flaws, etc. Waviness is due to the geometric errors of machine tool and varying stiffness of the machine tool. Roughness is due to the inherent kinematic differences of the cutting process. 
Various parameters of surface roughness i. e. $R_{a}, R_{z}, R_{\max }$ are measured by using Surface Roughness Tester - 211 Mitutoyo, Japan make, as shown in Fig.10. Centre line average (C. L. A.) or $\mathrm{R}_{\mathrm{a}}$ value is the arithmetic average roughness height. Average height difference between the five highest peaks and five lowest valleys within the traversing length are called peak to valley height $\left(\mathrm{R}_{\mathrm{z}}\right)$.

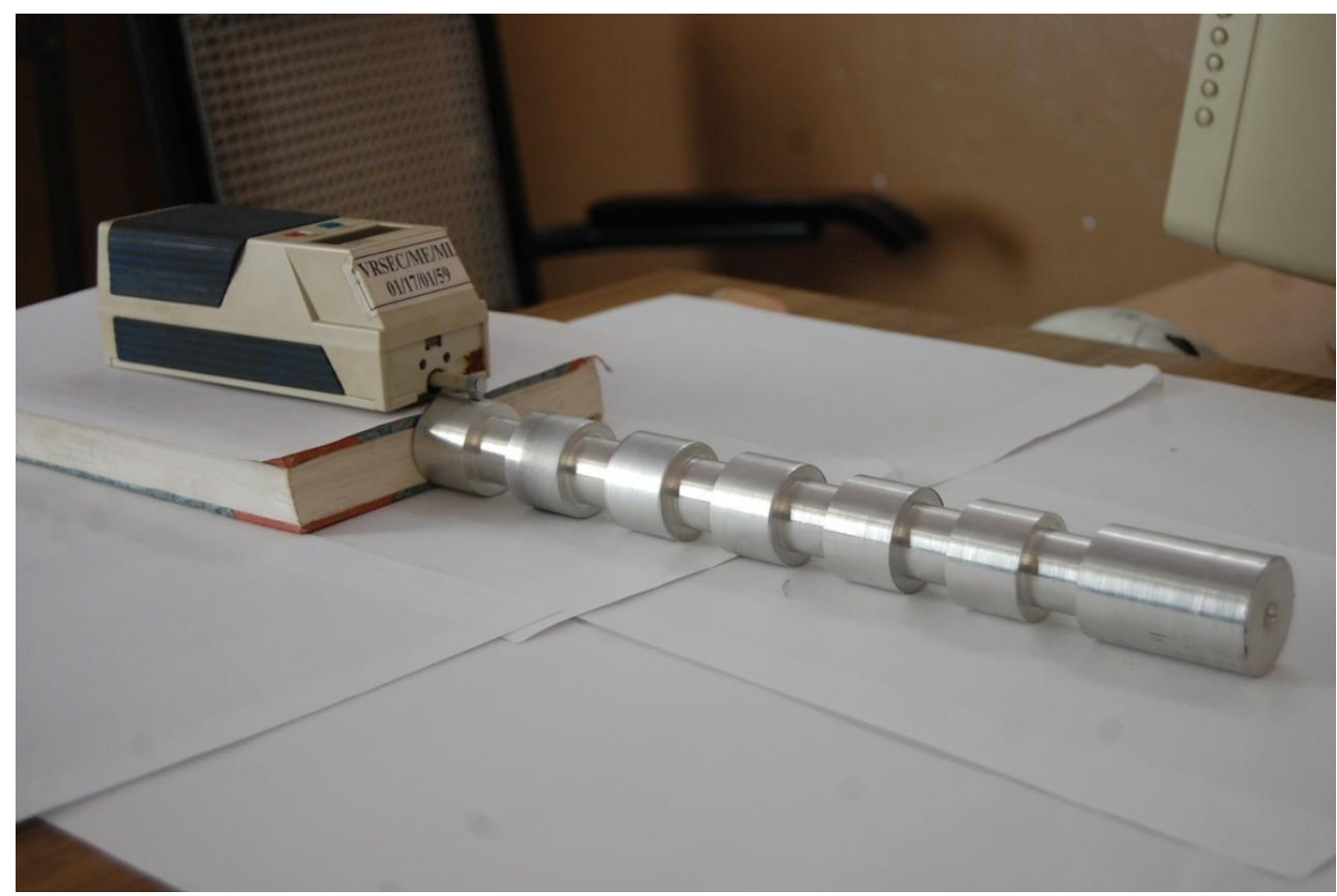

Fig. 10 Photograph of ‘Surftest - 211 model’ Surface Roughness Tester Aluminum

work piece is initially turned to $34 \mathrm{~mm}$ diameter with high speed steel single point tool on lathe with a spindle speed of $350 \mathrm{rpm}$ and $0.082 \mathrm{~mm} / \mathrm{rev}$ feed rate. The initial surface roughness value $R_{a}$ is measured. A roller of external diameter $40 \mathrm{~mm}$ and $12 \mathrm{~mm}$ width is used in the roller burnishing tool assembly. Constant spindle speed of $140 \mathrm{rpm}$ (burnishing speed $18 \mathrm{~m} / \mathrm{min}$ ) and constant feed rate of $0.060 \mathrm{~mm} / \mathrm{rev}$ is maintained throughout the experiment. A lathe tool dynamometer is used to measure the burnishing force. It is radial component of cutting force. It is $\mathrm{y}$ - component and it acts along the radial direction of the work piece. Various steps of the Aluminum work piece are burnished with different values of burnishing forces. The final surface roughness value, $R_{a}$ is measured in all these experiments, as shown in Table 1.

\section{ANALYTICAL MODELLING}

Using numerical approach, compressive residual stress is calculated. Roughness is considered as a triangular asperity in this numerical approach. Before burnishing, the height of the triangle is considered as the roughness of the work piece. The normal force is acting on the peak of the asperity. Fig. 11 represents the triangular model for numerical approach. The depth of deformed layer depends on the yield strength of the material $\left(\sigma_{y}\right)$, normal load $\left(F_{n}\right)$, and the asperity angle $(\alpha)[6]$. 
International Journal of Design and Manufacturing Technology (IJDMT), ISSN 0976 - 6995(Print), ISSN 0976 - 7002(Online) Volume 2, Issue 1, January-December (2011), @ IAEME

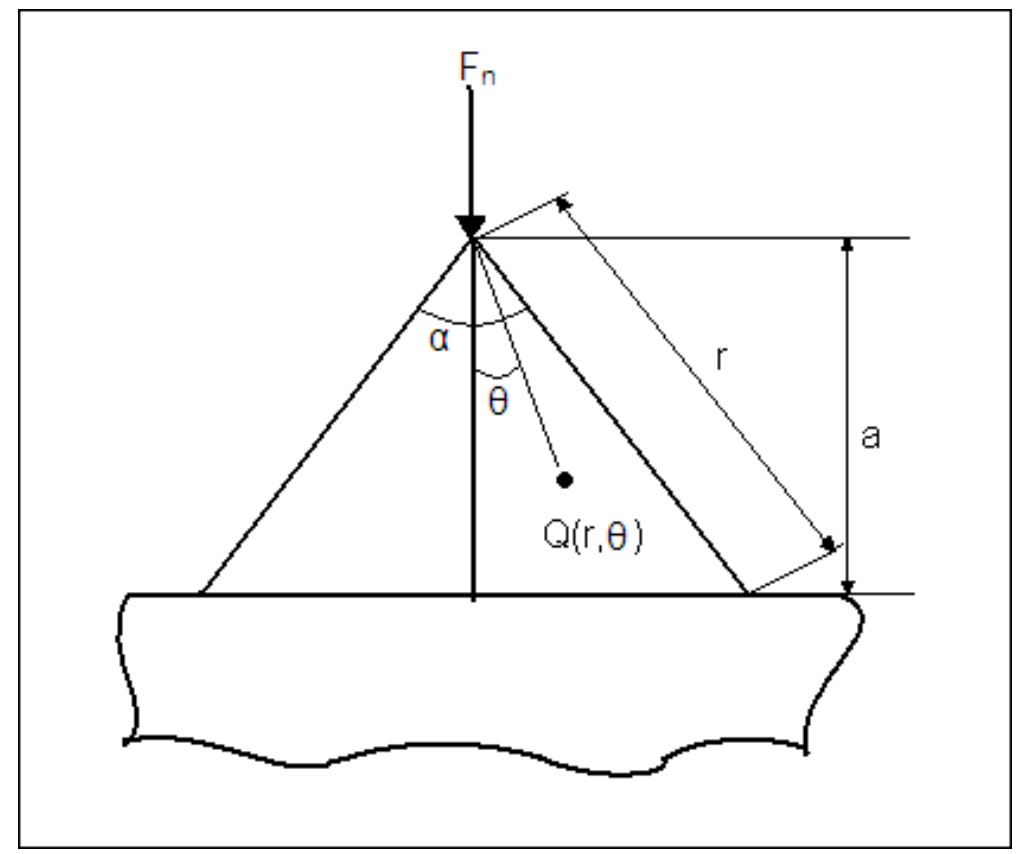

Fig. 11 Coordinates of a point $\mathrm{Q}(\mathrm{r}, \theta)$ within a triangular asperity

The radial stress at point $\mathrm{Q}(\mathrm{r}, \theta)$ due to normal load $\mathrm{P}_{\mathrm{n}}$, is given by

$$
\sigma_{\mathrm{r}, \theta}=\mathrm{F}_{\mathrm{n}} \cos \theta /(\alpha+1 / 2 \sin \alpha) \mathrm{r}
$$

where ' $a$ ' is the height of asperity and ' $r$ ' is length of flank.

Every point in the asperity is assumed to be attained the plastic state before the valleys are filled with the peaks, the stress at $\mathrm{Q}(\mathrm{r}, \theta)$ may be equal to the yield strength $\left(\sigma_{\mathrm{y}}\right)$ of the material. $\sigma_{\mathrm{y}}=\mathrm{F}_{\mathrm{n}} \cos (\alpha / 2) /(\alpha+1 / 2 \sin \alpha) \mathrm{r}$.

Substituting, $\mathrm{r}=(\mathrm{a} / \cos (\alpha / 2))$, we get

$$
\sigma_{\mathrm{y}}=\mathrm{F}_{\mathrm{n}} \cos ^{2}(\alpha / 2) /(\alpha+1 / 2 \sin \alpha) \mathrm{a} .
$$

\section{FINITE ELEMENT APPROACH}

Commercially available FEA package ANSYS- 12 is used to simulate the analysis process. The burnishing process is modeled as 2 D FEA and the surface roughness is considered as a triangular asperity with included angle of $80^{\circ}$. The height of the triangular asperity is considered as the surface roughness before burnishing, i. e., $3.66 \mu \mathrm{m}$ for Aluminum work piece. The FEA model is shown in Fig. 12. 


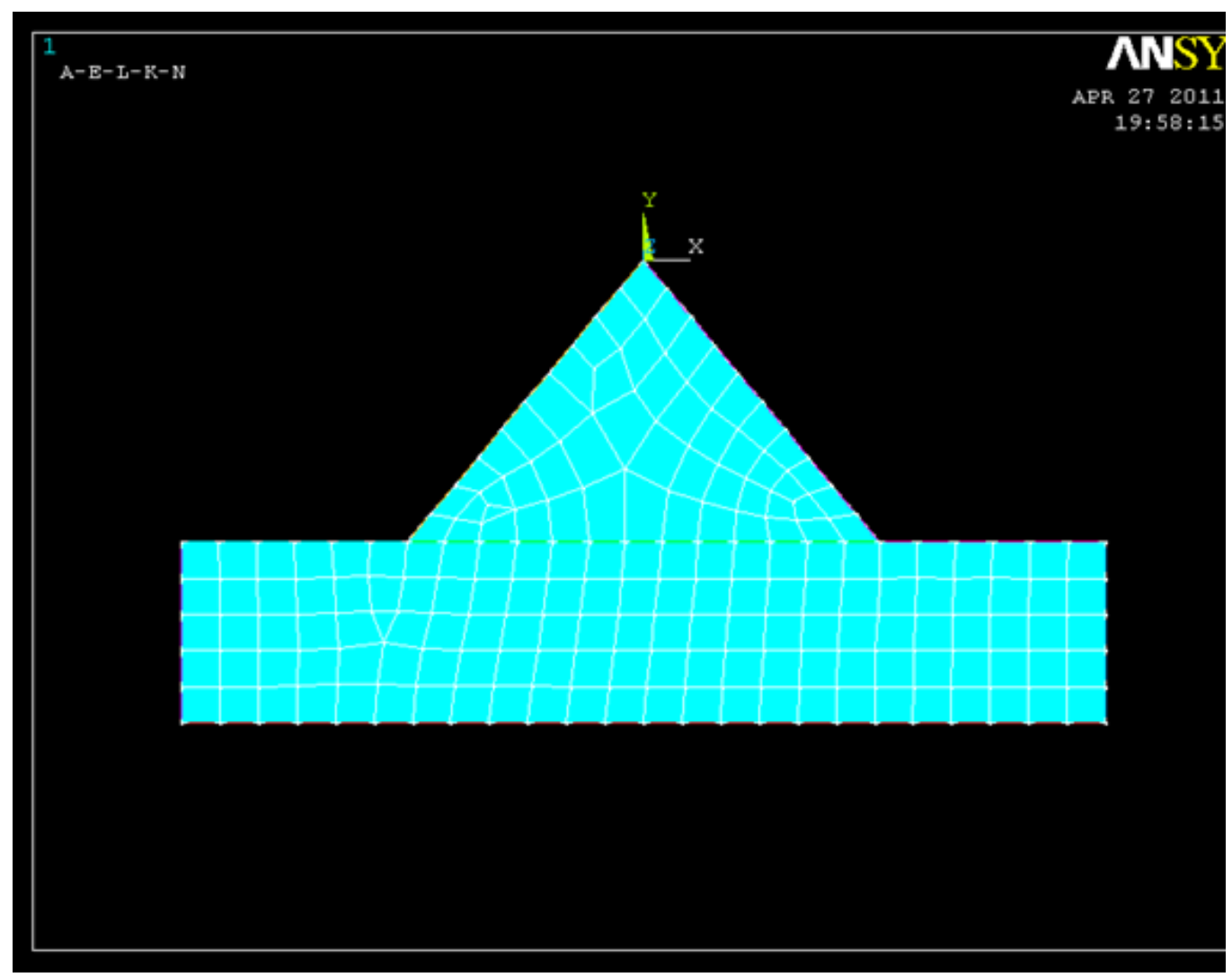

Fig. 12 Finite Element Model for work piece in Roller Burnishing.

The material properties of Aluminum work piece, used in the FEA are shown in the Table. 1. PLANE-42, 2- D structural solid element is selected for the analysis.

Table 1: Material properties of Aluminum work piece

\begin{tabular}{|c|l|l|l|l|l|}
\hline Material & \multirow{2}{*}{$\begin{array}{c}\text { Young's } \\
\text { modulus } \\
(\mathrm{Mpa})\end{array}$} & \multicolumn{2}{|c|}{ Yield Strength (Mpa) } & Poison ratio \\
\cline { 3 - 5 } & & Min & Max & $\begin{array}{c}\text { Density } \\
\mathrm{kg} / \mathrm{m}^{3} \\
\rho\end{array}$ \\
\hline Aluminum & $0.7 \times 10^{5}$ & 35 & 550 & 0.34 & 2,700 \\
\hline
\end{tabular}

\section{RESULTS AND DISCUSSIONS}

\subsection{SURFACE ROUGHNESS}

The effect of burnishing force on the surface roughness for Aluminum is shown in Fig. 13. It is observed from the graph that as the force increases, the surface roughness decreases up to an optimum force. Beyond the optimum force, the surface roughness increases. The reason for this is explained below.

Initially, as the force increases, then the penetration depth of the roller inside the work piece surface will be increased, leading to a smoothening of the surface. If the burnishing force is increased after a certain value (optimum), due to the higher work hardening induced into the surface by the increase in the amount of plastic deformation, flaking of the surface will take place, there by the surface roughness increases. 
International Journal of Design and Manufacturing Technology (IJDMT), ISSN 0976 - 6995(Print), ISSN 0976 - 7002(Online) Volume 2, Issue 1, January-December (2011), @ IAEME

Comparison of the practical and FEA values are presented in the Table: 2 for Aluminum material. The deformed shapes of the Aluminum material in Finite Element Model are shown in Fig. 14.

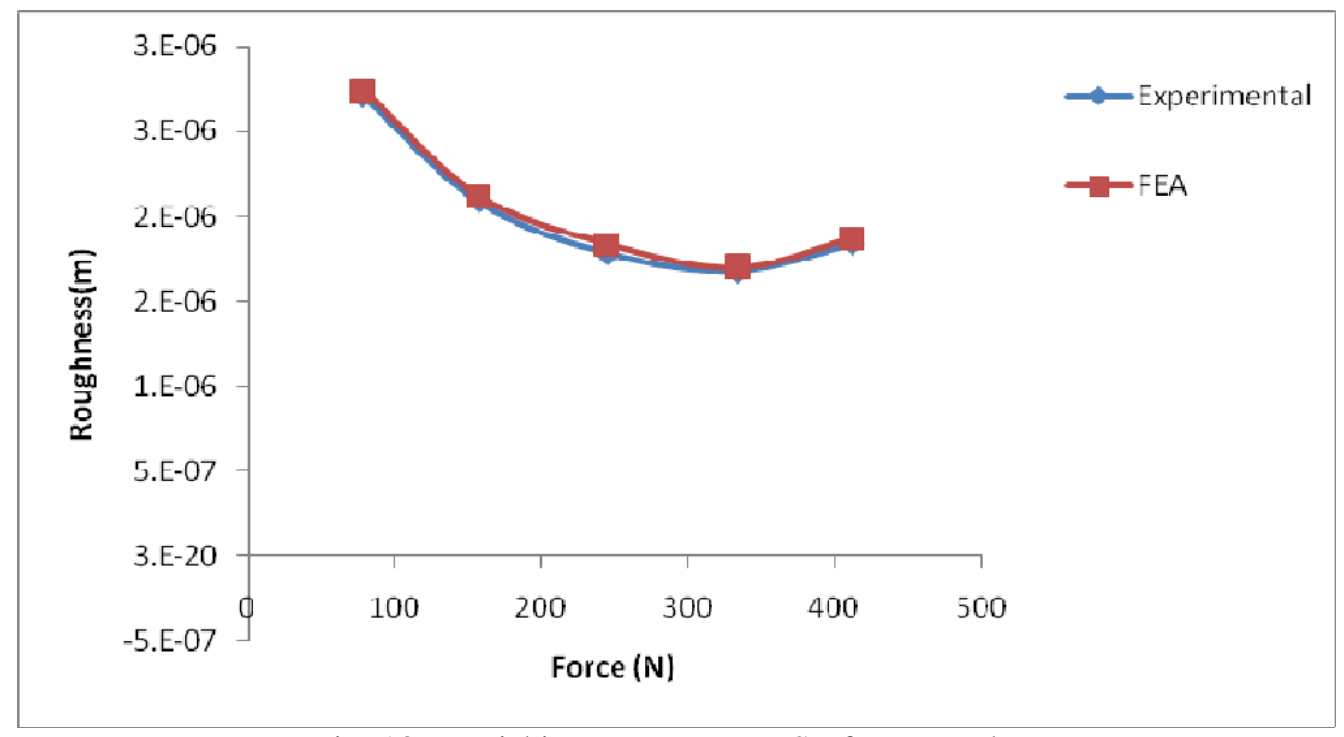

Fig. 13 Burnishing Force versus Surface Roughness

Table: 2. Surface Roughness values for different forces on Aluminum work piece

\begin{tabular}{|c|c|c|c|c|}
\hline \multirow{2}{*}{ Force(N) } & \multicolumn{2}{|c|}{ Surface Roughness $(\mu \mathrm{m})$} & Deviation & $\begin{array}{c}\text { Error } \\
(\%)\end{array}$ \\
\cline { 2 - 3 } & Experimental & FEA & 0.03 & 1.1 \\
\hline 78.48 & 2.71 & 2.74 & 0.03 & 1.43 \\
\hline 156.96 & 2.09 & 2.12 & 0.06 & 3.3 \\
\hline 245.25 & 1.78 & 1.84 & 0.02 & 1.78 \\
\hline 333.54 & 1.68 & 1.70 & 0.03 & 1.63 \\
\hline 412.02 & 1.84 & 1.87 & & \\
\hline
\end{tabular}




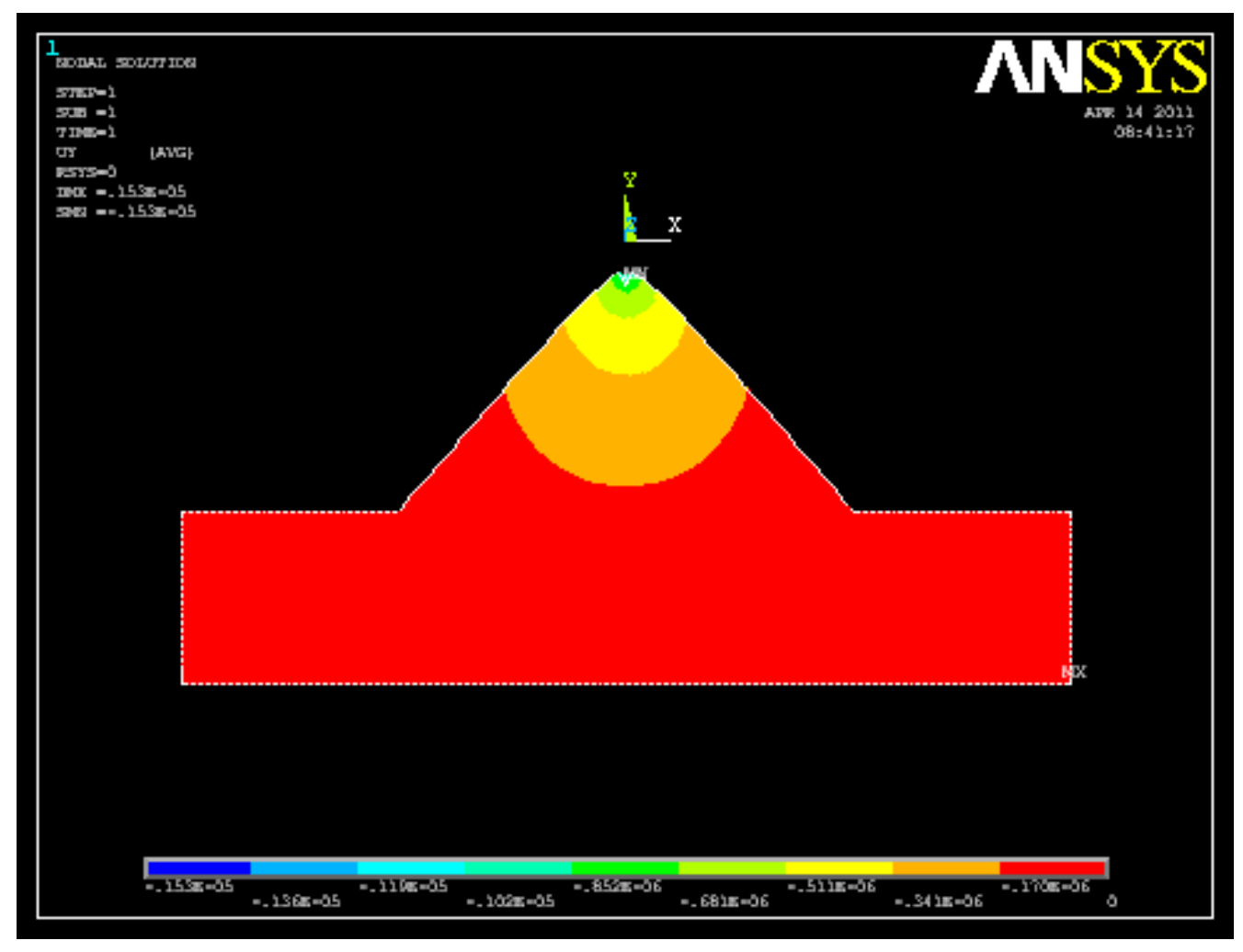

Fig. 14 Deformation at optimum Burnishing Force on Aluminum work piece.

\subsection{RESIDUAL STRESSES}

The principal advantage in the burnishing process is the induction of compressive residual stresses. The stresses are calculated analytically by using the equation 3 . The induced stresses are observed from the FEA and analytical values are presented in the Table 4 for Aluminum work piece. As the burnishing forces are increased, the stresses are increased. The stress distributions are presented in the Fig. 15 for Aluminum work piece.

The compressive residual stresses obtained through Analytical and FEA are compared and plotted in the Fig. 16 for Aluminum. It can be observed from the graph that as the force increases residual stresses are also increasing.

Table: 4. Residual Stresses for Aluminum work piece

\begin{tabular}{|c|c|c|c|c|}
\hline \multirow{2}{*}{ Force(N) } & \multicolumn{2}{|c|}{ Residual Stress (MPa) } & \multirow{2}{*}{ Deviation } & \% error \\
\cline { 2 - 3 } & Experimental & FEA & & 5.9 \\
\hline 78.48 & 43.5 & 46.24 & 2.74 & 7.9 \\
\hline 156.96 & 72.2 & 78.425 & 6.23 & 6.5 \\
\hline 245.25 & 107 & 114.556 & 7.56 & 9.7 \\
\hline 333.54 & 141 & 156.25 & 15.25 & 8.9 \\
\hline 412.02 & 167 & 183.5 & 16.5 & \\
\hline
\end{tabular}


International Journal of Design and Manufacturing Technology (IJDMT), ISSN 0976 - 6995(Print), ISSN 0976 - 7002(Online) Volume 2, Issue 1, January-December (2011), @ IAEME

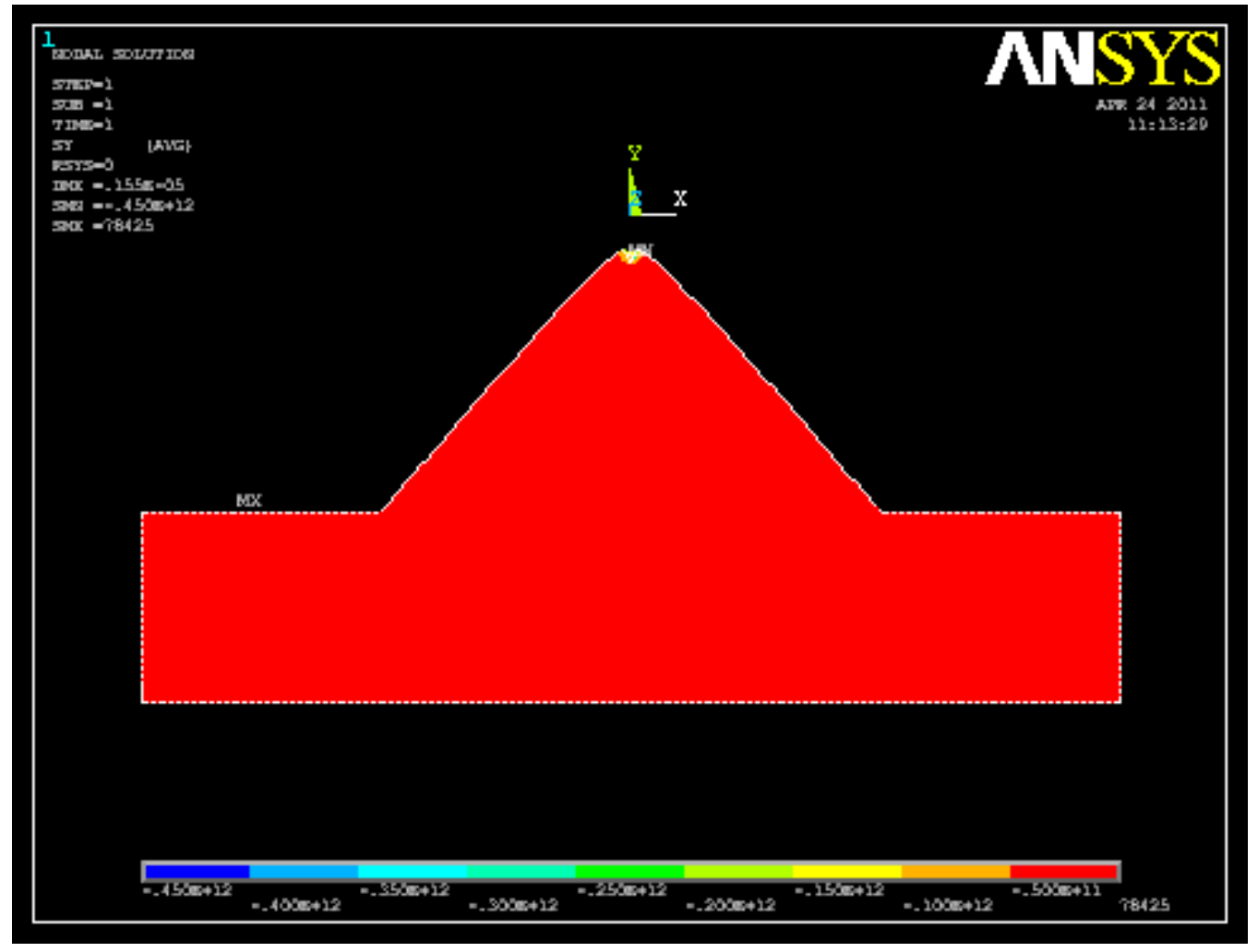

Fig. 15 Residual Stress distribution in Aluminum work piece

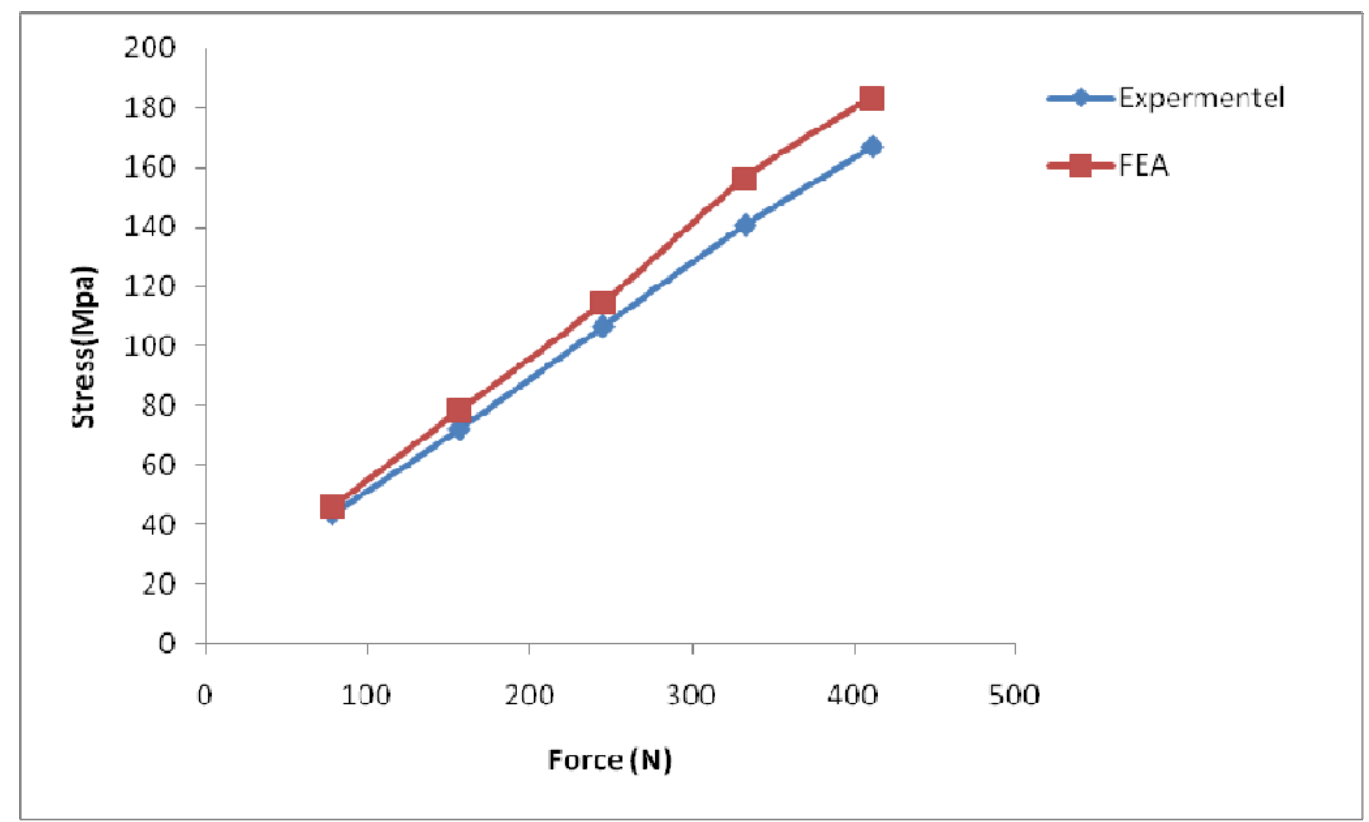

Fig. 16 Burnishing Force versus Compressive Stresses in Aluminum work piece 
International Journal of Design and Manufacturing Technology (IJDMT), ISSN 0976 - 6995(Print), ISSN 0976 - 7002(Online) Volume 2, Issue 1, January-December (2011), @ IAEME

\section{CONCLUSIONS}

The following conclusions are drawn from the above experiments.

1. Roller burnishing is a method of producing very good surface finish. Also, it produces an accurately sized, finely finished and densely compacted surface that resists wear. The surface roughness value, $R_{a}=1.68 \mu \mathrm{m}$ is obtained for aluminum work piece from the experiment. Percentage reduction in surface roughness is found to be $54 \%$ for Aluminum work piece.

2. It is concluded that compressive residual stresses are developed on the surface of the aluminum work piece and they are increased with the burnishing force.

3. The Finite Element Analysis is carried out and the results are coinciding with the values got from the experimental results. From the table, the variations can be obtained and the error is less than $10 \%$.

4. Roller burnishing produces better and accurate surface finish on aluminum work piece in a smaller time. It is an economical process, where skilled operators are not required.

\section{REFERENCES}

[1] Shneider, Yu. G., 1967, "Characteristics of burnished components", Mechanical Tooling, 38 (1), pp.19-22.

[2] Murthy R. L., and Kotiveerachary B., 1981, "Burnishing of Metallic Surfaces - A

Review”, Precision Engineering J., 3, pp.172 - 179.

[3] Hassan A.M., 1997, "The effects of ball and roller burnishing on the surface roughness and hardness of some non-ferrous metals", J. Materials Processing Technology, 72, pp.385 -391 .

[4] Thamizhmnaii S, Bin Omar B., Saparudin S. and Hassan S., 2008, "Surface roughness investigation and hardness by burnishing on titanium alloy", J. Achievements in Materials and Manufacturing Engineering, 28, pp.139 - 142 .

[5] Loh N. H., Tam S. C. and Miyazawa S., 1991, "Investigations on the surface roughness produced by Ball Burnishing”, Int. J. Machine Tools Manufacture, 31, pp.75-81.

[6] Kotiveerachari B., and Murthy R. L., 1984, "Study of optimum force in burnishing", All India Machine Tool design and research conference, IIT- Madras.

[7] Siva Prasad T., and Kotiveerachari B., 1988, "External burnishing of Aluminum components", J. Inst. Eng. India, 69, pp. 55-58.

[8] C. Poussard C., Pavier M. J., Smith D. J., 1995, "Analytical and Finite Element Predictions of Residual Stresses in Cold Worked Fastener Holes", J. Strain Analysis, 30 (4), pp. 291- 304.

[9] O. C. Zienkiewiez R. L. Taylor, 1991, "The Finite Element Methods", 2, 4 e, McGraw

Hill Book Company, Singapore, pp. 211-341.

[10] Pavier M. J., Poussard C. G. C., and Smith D. J., 1997, “A Finite Element Simulation of the Cold Working Process for Fastener holes", J. Strain Analysis, 32 (4), pp. 287-300.

[11] Papanikos P., and Meguid S. A., 1998, "Three Dimensional Finite Element Analysis of Cold Expansion of Adjacent Holes”, Int. J. Mechanical Science, 40 (1), pp. 1019-1028. 